\title{
PEMBENTUKAN KARAKTER MANDIRI ANAK MELALUI KEGIATAN NAIK TRANSPORTASI UMUM
}

\author{
Deana Dwi Rita Nova', Novi Widiastuti² \\ 1,2IKIP Siliwangi \\ 1deanadwi35@gmail.com
}

\begin{abstract}
ABSTRAK
Pendidikan karakter mandiri adalah usaha sadar yang dilakukan untuk membentuk watak, akhlak, budi pekerti, dan mental seorang individu, agar hidupnya tidak bergantung pada bantuan orang lain dalam menyelesaikan setiap tugas-tugasnya. Terdapat beberapa nilai-nilai dalam pendidikan karakter yang harus dikembangkan, salah satunya adalah nilai karakter mandiri. Karakter mandiri pada anak, dapat aplikasikan melalui kegiatan sehari-harinya. Melalui kegiatan keseharian anak, nilai karakter mandiri dapat langsung diajarkan dan diterapkan sehingga anak terbiasa dan belajar mandiri melakukan dan menyelesaikan tuganya, tanpa membutuhkan bantuan dari orang lain khususnya oleh orangtuanya. Tujuan dari penelitian ini adalah untuk mendeskripsikan pembentukan karakter mandiri anak melalui kegiatan naik transportasi umum. Mandiri merupakan sikap atau perilaku seorang individu melakukan segala aktivitasnya sendiri tanpa harus bergantung dan tanpa bantuan pada orang lain. Indikator kemandirian dapat dilihat dari empat aspek, yaitu: memiliki hasrat untuk bersaing, mampu mengambil keputusan dan menghadapi masalah yang dihadapi, memiliki kepercayaan diri, dan memiliki rasa tanggungjawab. Penelitian ini adalah jenis penelitian deskriptif dengan menggunakan pendekatan kualitatif. Teknik pengumpulan data yang digunakan dalam penelitian ini adalah melalui observasi atau pengamatan secara langsung dan wawancara. Berdasarkan hasil wawancara terhadap orangtua dan gurunya, anak-anak tersebut memiliki nilai karakter mandiri bila dibandingkan teman seusianya. Nilai karakter mandiri yang dimiliki anak-anak tersebut meliputi: mereka memiliki rasa peduli dan empati atau kepekaan terhadap lingkungan, lebih percaya diri dan menghargai orang lain, mampu mengendalikan emosi, menahan diri dan bersabar, mampu membuat keputusan dan memiliki rasa tanggung jawab. Kesimpulanya pembentukan karakter mandiri pada anak dapat dilakukan melalui kegiatan naik transportasi umum. Karena melalui transportasi anak dapat belajar secara langsung mengenai lingkungan sekitarnya.
\end{abstract}

Kata Kunci: Pembentukkan Karakter Mandiri Anak, Transportasi Umum

\section{PENDAHULUAN}

Pendidikan karakter merupakan salah satu program pendidikan yang gencar disosialisasikan dan digerakan beberapa tahun terakhir, yang bertujuan untuk menekan tingkat kriminalitas oleh anak dan membentuk karakter anak. Karakter memiliki tiga bagian yang saling berhubungan, yaitu pengetahuan moral, perasaan moral dan perilaku moral (Lickona, 2015). Ketiga hal tersebut diperlukan dalam membetuk moral kehidupan. Terdapat beberapa nilai-nilai dalam pendidikan karakter yang harus 
dikembangkan, salah satunya adalah nilai karakter mandiri. Mandiri merupakan sikap atau perilaku seorang individu yang tidak mudah bergantung pada orang lain. Pendidikan karakter mandiri adalah usaha sadar yang dilakukan untuk membentuk watak, akhlak, budi pekerti, dan mental seorang individu, agar hidupnya tidak bergantung pada bantuan orang lain dalam menyelesaikan setiap tugas-tugasnya.

Menurut Kamus Besar Bahasa Indonesia, mandiri adalah keadaan dapat berdiri sendiri; tidak bergantung pada oranglain. Kata bendanya adalah kemandirian yang berarti hal atau keadaan dapat berdiri sendiri tanpa bergantung pada orang lain. Kemandirian dapat dilihat dari tiga aspek yaitu: kemandirian emosianal yang menunjukan adanya perubahan hubungan emosional antar individu, kemandirian tingkah laku untuk membuat keputusan tanpa terpengaruh oleh orang lain dan dapat bertanggung jawab atas keputusan tersebut, kemandirian dalam memaknai prinsip tentang benar dan salah.

Karakter mandiri pada anak, dapat aplikasikan melalui kegiatan sehari-harinya. Melalui kegiatan keseharian anak, nilai karakter mandiri dapat langsung diajarkan dan diterapkan sehingga anak terbiasa dan belajar mandiri melakukan dan menyelesaikan tuganya, tanpa membutuhkan bantuan dari orang lain khususnya oleh orangtuanya. Kegiatan tersebut meliputi bangun sendiri, mandi sendiri, memakai pakaian sendiri bahkan berangkat sekolah sendiri. Berk (2005) mengemukakan bahwa secara bertahap anak-anak dari usia dua hingga enam tahun mulai mandiri dalam melakukan kegiatan berpakaian dan makan. Berdasarkan pendapat tersebut dapat dijelaskan bahwa kemandirian anak dapat dibentuk sedari kecil melalui kegiatan sederhana, sebagai bagian dari kebiasaan dalam kegiatan sehari-hari.

Selin itu, salah satu upaya untuk menanamkan karakter mandiri pada anak dapat dilakukan dengan mengenalkan pada transportasi umum dan membiasakan anak untuk naik transportasi umum. Tranposrtasi umum dapat menjadi media belajar yang baik bagi dalam membentuk karakter kemandiriannya. Dengan naik transportasi umum anak belajar berinteraksi dengan lingkungan dan orang sekitarnya, anak belajar menghadapi situasi sulit tanpa bantuan orangtuanya, dan anak belajar menghormati dan manghargai orang lain. Oleh karena itu, dengan mengajarkan anak naik transportasi umum diharapkan dapat membentuk karakter mandiri pada anak.

Menurut salah seorang Pakar Psikologi Klinis dari Universitas Indonesia, mengatakan bahwa memperkenalkan anak pada transportasi umum merupakan kegiatan yang baik. Karena anak dapat meninggalkan zona nyaman mereka yang biasa mereka dapatkan dari kendaraan pribadi yang orang tua mereka miliki. Selain itu, dengan menaiki transportasi umum anak dapat melatih kesabaran, kemandirian, menumbuhkan keberanian dan melatih kepekaan terhadap lingkungan dengan berinteraksi secara langsung dengan orang banyak.

Orangtua di Jepang membiasakan anak mereka untuk naik transportasi umum tanpa didampingi oleh orangtua sejak usia empat tahun. Bahkan tata cara menaiki transportasi umum merupakan salah satu mata pelajaran yang diajarkan di Taman Kanak-kanak. Tidak dapat dipungkiri, meski orangtua di Jepang membiarkan anak-anak mereka bepergian sendiri, tetap ada rasa khawatir dalam diri mereka. Oleh karena itu, untuk menjaga keamanan dan keselamatan anak-anak tersebut diberlakukan aturan, agar anak-anak pergi dan pulang sekolah secara berkelompok dengan anak lain yang tinggal di lingkungan yang sama. Selain itu, setiap anak di Jepang memiliki kartu identitas yang berisi infornasi mengenai nama dan alamat rumah mereka, sehingga saat 
mereka tersesat dapat dengan mudah diantar pulang ke rumah. Kemandirian memang merupakan identitas Jepang yang menjadi pembeda dengan negara lain, dengan tingkat kriminalitas yang rendah dan transportasi umum yang nyaman membuat hal ini tidak sulit untuk diterapkan.

Di indonesia, rasa khawatir orangtua masih mendominasi untuk membiarkan anak untuk bepergian sendiri. Bahkan orangtua terbiasa mengantar dan menjemput anaknya ke sekolah dengan alasan lebih aman dan nyaman bila ada yang mengawasi. Lingkungan yang dirasa kurang aman dan transportasi yang kurang nyaman menjadi faktor pertimbangan orangtua. Seiring perkembangan teknologi, transportasi umum di Indonesia juga mengalami kemajuan, pemerintah fokus untuk menciptakan transportasi umum yang aman dan nyaman. Sehingga saat ini terdapat banyak transportasi umum yang ramah dan nyaman bahkan bagi anak-anak. Oleh sebab itu, terdapat orangtua yang mendidik anaknya dengan naik transportasi umum untuk pergi dan pulang sekolah sendiri. Tujuan dari penelitian ini adalah untuk mendeskripsikan pembentukan karakter mandiri anak melalui kegiatan naik transportasi umum.

\section{LANDASAN TEORITIS}

\section{Definisi karakter mandiri}

Mandiri merupakan sikap atau perilaku seorang individu melakukan segala aktivitasnya sendiri tanpa harus bergantung dan tanpa bantuan pada orang lain. Menurut Mustari (2011) mandiri adalah sikap dan perilaku yang tidak mudah bergantung pada orang lain dalam menyelesaikan tugas-tugas.

Desmita (2009) menyatakan bahwa kemandirian mengandung beberapa pengertian, diantaranya: 1) suatu kondisi dimana seseorang memiliki hasrat untuk bersaing dangan orang lain untuk maju demi kebaikan diri sendiri; 2) mampu mengambil keputusan dan inisiatif untuk mengatasi masalah yang dihadapi; 3) memiliki kepercayaan diri dalam melaksanakan tugas-tugasnya; dan 4) bertanggung jawab atas setiap tindakan yang dilakukannya. Berdasarkan pendapat tersebut, dapat disimpulkan indikator kemandirian dapat dilihat dari empat aspek, yaitu: memiliki hasrat untuk bersaing, mampu mengambil keputusan dan menghadapi masalah yang dihadapi, memiliki kepercayaan diri, dan memiliki rasa tanggungjawab.

\section{Definisi Transportasi}

Transportasi merupakan layanan jasa yang berguna untuk memindahkan atau membawa orang maupun barang dari satu tempat menuju ke tempat lain. Transportasi adalah sarana fasilitas yang sering digunakan oleh masyarakat untuk menunjang segala aktivitasnya yang tidak dapat dipisahkan dari kehidupan sehari-harinya. Menurut Miro (2005) dalam buku Andriansyah (2015) transportasi dapat diartikan sebagai usaha memindahkan, menggerakkan, mengangkut, atau mengalihkan suatu objek dari suatu tempat ke tempat lain, dimana ditempat lain objek tersebut lebih bermanfaat atau dapat berguna untuk tujuan-tujuan tertentu. Sedangkan menurut Nasution (2008) dalam buku Andriansyah (2015) transportasi adalah sebagai media memindahkan barang atau manusia dari tempat asal ke tenpat tujuan.

Manfaat transportasi bagi anak menurut salah seorang Pakar Psikologi Klinis dari Universitas Indonesia adalah pertama, untuk melatih kesabaran. Dimana anak berlatih utnuk bersabar menunggu kedatangan transportasi umum yang tidak pasti, bersabar menahan rasa panas dan berdesak-desakkan di dalam transportasi umum dan bersabar menunggu giliran untuk naik dan turun. Kedua, menumbuhkan keberanian, diaman 
anak belajar menghadapi dunia yang dipenuhi dengan banyaknya orang asing dengan tanpa didampingi oleh orangtua maupun erabat yang dikenalnya. Dan ketiga, melatih kepekaan anak terhadap lingkungannya, karena anak berinterasksi dengan berbagai macam manusia dalam transportasi massal, seperti anak lain yang seusia dengannya, para pedagang, karyawan kantor dan sebagainya, sehingga anak belajar untuk menghargai orang lain.

\section{METODE PENELITIAN}

Penelitian ini adalah jenis penelitian deskriptif dengan menggunakan pendekatan kualitatif. Teknik pengumpulan data yang digunakan dalam penelitian ini adalah melalui observasi atau pengamatan secara langsung dan wawancara yang dilakukan terhadap orangtua dan guru dari delapan orang peserta didik dengan rentang usia sekolah dasar di Desa Padalarang yang menjadi subjek dalam penelitian ini.

\section{PEMBAHASAN}

Transportasi merupakan hal yang tidak dapat dipisahkan bagi keseharian masyarakat dalam menunjang kehidupannya. Masyarakat biasa menggunakan transportasi untuk melakukan segala aktivitasnya, baik untuk bekerja, sekolah, kuliah, menuju ke suatu tempat perbelanjaan atau pusat kesehatan maupun untuk rekreasi. Transportasi sangat lumrah ditemui. Transportasi diciptakan dengan tujuan memudahkan manusia ataupun barang dalam menempuh perjalanan ke tempat tujuan dan mempersingkat waktu. Dilihat dari segi penggunanya, transportasi dapat terbagi menjadi dua yaitu transportasi pribadi dan transportasi umum. Transportasi umum yang terdapat di Indonesia diantaranya kereta api, bus, ojek, becak, delman, angkot dan sebagainya.

Transportasi merupakan layanan jasa yang berguna untuk membawa orang ataupun barang dari suatu tempat menuju ke tempat lain. Bila dilihat dari sudut pandang pendidikan transportasi dapat dijadikan sebagai media pembelajaran bagi anak, salah satunya sebagai upaya membentuk karakter mandiri pada anak. Hal ini terbukti dari delapan anak dengan rentang usia sekolah dasar yang menjadi subjek penelitian, berdasarkan hasil wawancara terhadap orangtua dan gurunya, anak-anak tersebut memiliki nilai karakter mandiri yang lebih unggul bila dibandingkan teman seusianya.

Secara sosial, anak-anak tersebut menunjukkan rasa peduli dan kepekaan terhadap lingkungan yang cukup baik, berdasarkan wawancara anak-anak tersebut akan membantu temannya yang mengalami kesulitan, salah satunya dalam kegiatan belajar. Mereka menunjukkan kecenderungan untuk membantu rekan mereka untuk menjelaskan kembali soal maupun pelajaran yang kurang dipahami oleh rekan mereka. Hal tersebut terjadi karena hampir setiap hari mereka melihat dan memperhatikan secara langsung lingkungan sekitar saat melakukan perjalanan pergi dan pulang ke sekolah dan berinteraksi dengan orang yang mereka temui di jalan raya maupun di dalam angkot.

Secara emosional, anak-anak tersebut mampu menahan diri dan mengendalikan emosi dengan cukup baik, berdasarkan hasil wawancara anak-anak yang terbiasa bepergian sendiri menggunakan transportasi umum menunjukkan pengendalian emosi yang cukup baik, dimana mereka tidak mudah marah bila ada rekan yang menyinggungnya. Mereka cenderung lebih tenang dan malah menjadi penengah bila ada rekan yang berkelahi. Hal tersebut dipengaruhi oleh kebiasaan mereka menunggu angkot dan bersabar dalam mengantri dan menunggu giliran untuk naik dan turun angkot. Selain itu, berdasarkan hasil wawancara anak-anak memiliki kepercayaan diri yang cukup 
tinggi, ini disebabkan karena mereka terbiasa berinteraksi dan tampil dihapadan orang banyak dan berani bertanya pada orang lain. Secara kognitif atau pengetahuan, anak mampu menyelesaikan masalah yang dia hadapi serta mampu mengambil keputusan dengan mempertimbangkannya terlebih dahulu. Dengan kemampuan tersebut, anak akan mempelajari sistem proses pembelajaran secara langsung dari masyarakat atau kehidupan sosial dan ini memberikan nilai yang lebih baik daripada pendekatan teoritis semata (Saepudin \& Mulyono, 2019). Senada dengan pendapat dari Samsudin dan Ansori (2013) yang mengutarakan bahwa proses pembelajaran di tengah masyarakat merupakan proses pendidikan nonformal yang paling baik untuk membangun karakter anak di masa yang akan datang.

\section{KESIMPULAN}

Transportasi merupakan layanan jasa yang berguna untuk membawa orang ataupun barang dari suatu tempat menuju ke tempat lain. Bila dilihat dari sudut pandang pendidikan transportasi dapat dijadikan sebagai media pembelajaran bagi anak, salah satunya sebagai upaya membentuk karakter mandiri pada anak. Hal tersebut karena banyaknya manfaat menaiki transportasi umum bagi anak diantaranya: dapat melatih kesabaran, kemandirian, menumbuhkan keberanian dan melatih kepekaan terhadap lingkungan dengan berinteraksi secara langsung dengan orang banyak. Berdasarkan hasil wawancara terhadap orangtua dan guru dari delapan anak dengan rentang usia sekolah dasar yang menjadi subjek penelitian, anak-anak tersebut memiliki nilai karakter mandiri yang lebih unggul bila dibandingkan teman seusianya.

\section{DAFTAR PUSTAKA}

Andriansyah. (2015). Manajemen Transportasi dalam Kajian dan Teori. Jakarta Pusat: Fakultas Ilmu Sosial dan Ilmu Politik Universitas Prof. Dr. Moestopo Beragama.

Ansori, A\& Samsudin, A. (2013). Transformasi Pembelajaran Di Pendidkan Non Formal (Upaya mempersiapkan pendidik dan peserta didik dalam menghadapi tantangan global untuk menjadi manusia pembelajar). Empowerment, 2(1), 1-15.

Berk. (2005). Infants, Children and Adolescense. New York: Pearson Education. Inc.

Desmita. (2009). Psikologi Perkembangan Peserta Didik. Bandung: PT Remaja Rosdakarya.

Kamus Besar Bahasa Indonesia. (2013). Dipetik Januari 9, 2019, dari https://kbbi.web.id/mandiri.html

Lickona, T. (2015). Character Matters: Persoalan Karakter, Bagaimana Membentu Anak Mengembangkan Penilaian Yang Baik, Integritas dan Kebajikan Penting Lainnya. Jakarta: PT Bumi Aksara.

Mustari, M. (2011). Nilai Karakter. Yogyakarta: LaksBang PRESSindo.

Nirmalasari \& Widiastuti. (2018). Peran Tokoh Pemuda Dalam Meningkatkan Partisipasi Karang Taruna Di Desa Nanjung Margaasih. Comm-Edu (Community Education Journal), 1(2), 94-104 
Puteri, A. (2017, Desember 13). Nakita.Grid.ID. Dipetik Januari 20, 2019, dari Grid.ID Network: http://nakita.grid.id/amp/0220055/moms-ini-manfaatnya-mengajaksi-kecil-naik-transportasi-umum?page=all

Sa'ida, N. (2016). Kemandirian Anak Kelompok A Taman Kanak-Kanak Mandiri Desa Sumber Asri Kecamatan Nglegok Kabupaten Blitar. Jurnal Pedagodi, 3 Vol. 2.

Saepudin \& Mulyono. Community Education In Community Development. Empowerment, Vol. 8(1), 65-73

TEMPO.CO. (2016, Maret 31). Dipetik Januari 25, 2019, dari https://gaya.tempo.co/amp/758566/saatnya-mengajarkan-anak-naikkendaraan-umum

TEMPO.CO. (2016, Desember 14). Dipetik Januari 25, 2019, dari https://cantik.tempo.co/amp/827685/mandiri-sejak-tk-membiasakan-anakpergi-sekolah-sendiri 